Article

\title{
Dependence of Fresh Grapes and Wine Taste Scores on the Origin of Varieties and Weather Conditions of the Harvest Year in the Northern Zone of Industrial Viticulture in Russia
}

\author{
Liubov Yu. Novikova ${ }^{1, *(1)}$ and Lyudmila G. Naumova ${ }^{2}$ \\ 1 N. I. Vavilov All-Russian Institute of Plant Genetic Resources (VIR), 42, 44, Bolshaya Morskaya Street, \\ 190000 St. Petersburg, Russia \\ 2 Ya. I. Potapenko All-Russian Research Institute for Viticulture and Winemaking, A Branch of the Federal \\ Rostov Agrarian Research Center, 166, Baklanovskiy Avenue, 346421 Novocherkassk, Russia; \\ LGnaumova@yandex.ru \\ * Correspondence: 1.novikova@vir.nw.ru
}

Received: 9 September 2020; Accepted: 19 October 2020; Published: 21 October 2020

check for updates

\begin{abstract}
Climate change affects all characteristics of grapes, including the taste of fresh berries and wine. The purpose of this study was to reveal the dependence of fresh grapes taste scores (GS) and wine taste scores (WS) on the origin of the varieties and weather conditions of the harvest year in the northern zone of industrial viticulture in Russia. The material used in the study were taste scores of 232 grape varieties from the Don Ampelographic Collection $\left(47^{\circ} 25^{\prime} \mathrm{N} 40^{\circ} 03^{\prime} \mathrm{E}\right)$ 1981-2019. The correlation analysis, ANOVA, and regression were used. It was shown that GS negatively correlated with productivity, and WS with the berry mass of variety. In recent decades, GS have increased in groups of varieties of various interspecies origin, and WS have not changed. Regression models revealed that the reason for GS improvement was in the growth of average temperature above $15^{\circ} \mathrm{C}$, while WS varied depending on the sum of precipitation for the period with temperatures above $20^{\circ} \mathrm{C}$, which did not have a reliable trend. Together with data on the growth of grape yield and sugar content, the results indicate that observed climate warming is favorable for grapevine cultivation in the northern zone of industrial viticulture in Russia.
\end{abstract}

Keywords: ampelographic collection; fresh grapes taste scores; wine taste scores; regression model; climate change

\section{Introduction}

Expert analysis of the organoleptic properties of food products is the main tool to assess consumer preferences [1,2]. Assessments of fresh berries taste and wine quality are made applying an expert method [3-5]. Expert assessments of the organoleptic quality of food products are an integral indicator of the interaction of chemical compounds that form the organoleptic properties of the product. There are models connecting the tasting evaluations with accurately measured quantitative indicators $[3,4,6,7]$; however, the measured scores of grape quality are indirect [8], the same "desired quality" can correspond to strikingly different compositional models [7], and the expert procedure remains the key to determining consumer preferences [2].

The climate warming of recent decades has led to earlier ripening, reduction in acidity, and increase in sugar content in grape varieties in different wine regions [9-15]. Climate factors affect grape composition, wine microbiology and chemistry, color, aroma, and sensory features [11,12]. The same 
effects are observed in Russian viticulture [16-19]. High temperatures may become excessive for grapes in traditional winemaking regions $[10,19]$.

The development of the vine under climate change requires constant monitoring to adapt agronomic practices to global changes $[13,14]$. Measures for the adaptation of viticulture can be planned based on the assessment of trends in changes in economically important traits [9-11], their agrometeorological analysis, and prediction [20-24]. These forecasts become the basis for optimizing the location of vineyards, irrigation standards, and other agricultural techniques $[7,13,25,26]$. However, the existing numerical agrometeorological methods are in need of the development of new and adjustment of old models, because their accuracy in new climatic conditions is insufficient [27].

Economic and technological properties of grapes are determined by terroir, biological characteristics of the variety and viticulture practices, as well as by weather conditions of a particular year $[16,17,28-33]$.

Temperature, precipitation, and solar radiation affect the year-to-year variation of the chemical and mechanical composition of berries, and, ultimately, their consumer properties [34-38]. In Russia, temperature is considered to be the main factor limiting the growth and development of crops. The temperature requirements of grapes are well known: the minimum temperature for the beginning and end of grapes vegetation is $10^{\circ} \mathrm{C}$, average temperature of the warmest month should be at least $16^{\circ} \mathrm{C}$, the maximum temperature should be lower than $35-40{ }^{\circ} \mathrm{C}$, winter temperature above $-15{ }^{\circ} \mathrm{C}-20^{\circ} \mathrm{C}$ for the uncovered viticulture, and above $-35^{\circ} \mathrm{C}$ with the usual methods of protection from the cold $[21,30,34,39,40]$. Precipitation is necessary at the beginning of the growing season for the development of buds and inflorescences, while dry periods are important for flowering and fruit maturation, and the hydrothermal coefficient for non-irrigated vineyards should be from 0.5 to 2.5 [34]. Large amounts of precipitation increase the yield and lower sugar content [34,41], but severe long-term water deficiency adversely affects the plant as a whole, negatively affects photosynthetic activity, causes leaf abscission, and collapses the ripening process, which reduces the quality of must and wine $[11,25,42]$. The zone of high-quality wine production in the northern hemisphere is limited by the average temperatures of $13-21^{\circ} \mathrm{C}$ in April-October [9]. The wine quality is higher in years with a higher temperature during ripening and lower in humid years $[9,34,38]$.

To predict the impact of weather and climate conditions on the quality of grapes and wine, various heat and moisture indices, as well as regression dependencies on the biochemical composition and weather conditions are used [3,6,41,42].

The purpose of this study was to reveal the dependence of fresh grapes taste scores (GS) and wine taste scores (WS) on the origin of the varieties and weather conditions of the harvest year in the northern zone of industrial viticulture in Russia.

\section{Materials and Methods}

\subsection{Experiment Location and Materials}

The data for the study were the observations 1981-2019 at the Don Ampelographic Collection of the Ya.I. Potapenko All-Russian Research Institute for Viticulture and Winemaking (a branch of the Federal Rostov Agrarian Research Center, Novocherkassk city, Rostov Region, $47^{\circ} 25^{\prime} \mathrm{N} 40^{\circ} 03^{\prime} \mathrm{E}$ ), in the northern zone of industrial viticulture in Russia (Figure 1). The collection is located on a steppe plateau. The elevation of the area above sea level is $90 \mathrm{~m}$, the terrain is undulating. Soils are represented by ordinary carbonate chernozems, not saline, with a high supply of digestible forms of phosphorus, medium supply of mobile potassium, enriched with calcium carbonates. The humus horizon thickness reaches $90 \mathrm{~cm}$. Ground water lies at a depth of 15-20 m and does not affect the development of vines. Grape varieties are cultivated on the Kober 5BB $(V$. Berlandieri Planch. $\times$ V. riparia Michx.) rootstock. The collection is planted with 10 bushes of each variety, the planting scheme is $3 \times 1.5 \mathrm{~m}$. Irrigation is not provided. The grape cultivation technology used is common for the northern zone of industrial viticulture in the Russian Federation [43]. 


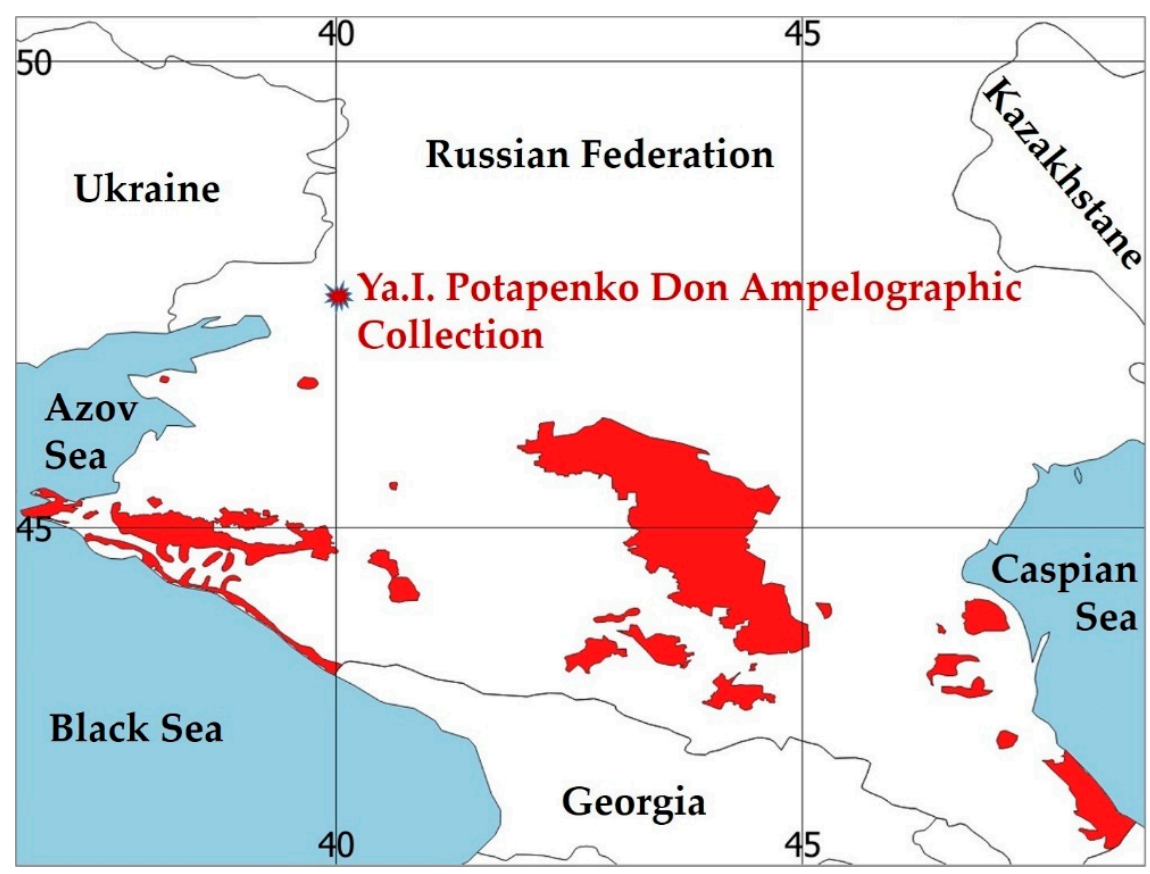

Figure 1. Ya.I. Potapenko Don Ampelographic Collection location. Map is taken from [44], modified. Red polygons-areas of industrial viticulture in Russia.

A total of 232 varieties were studied (Supplementary Table S1), including 77 wine, 118 table (13 seedless among them), and 37 multipurpose varieties (Table 1). The taste of fresh grapes was scored in 143 table and multipurpose varieties in 1981-2019, within 8 years on an average (from 1 to 28 for different varieties); the dry table wine taste was scored for 98 wine and multipurpose varieties in 2000-2019, within 4 years on an average (from 1 to 16 years for different varieties). The taste of both fresh grapes and wine was studied in 9 multipurpose varieties.

Table 1. Variability of test scores in groups of grape varieties of different types of use.

\begin{tabular}{ccccccccc}
\hline \multirow{2}{*}{ Type of Use } & \multicolumn{3}{c}{ Fresh Grapes Taste Score, Points } & \multicolumn{3}{c}{ Wine Taste Score, Points } \\
\cline { 2 - 8 } & $\begin{array}{c}\text { Number of } \\
\text { Varieties }\end{array}$ & Average Min & Max & $\begin{array}{c}\text { Number of } \\
\text { Varieties }\end{array}$ & Average Min & Max \\
\hline Wine & 0 & - & - & - & 77 & 8.6 & 8.3 & 8.8 \\
Multipurpose & 25 & 7.3 & 6.7 & 7.9 & 21 & 8.5 & 8.2 & 8.7 \\
Table & 118 & 7.7 & 6.6 & 8.5 & 0 & - & - & - \\
Total & 143 & 7.7 & 6.6 & 8.5 & 98 & 8.6 & 8.2 & 8.8 \\
\hline
\end{tabular}

Earlier, we found that the main differentiating features of the Don Ampelographic Collection are the type of use, origin (the presence of other species of the genus Vitis in the pedigree), and the ripening time [16]. From the point of view of origin, four groups of varieties are distinguished: 139 varieties of $V$. vinifera $L$.; 47 hybrids of $V$. vinifera $L$. with several American species; 25 hybrids $V$. vinifera $L . \times V$. amurensis Rupr.; and 13 interspecific hybrids V. vinifera L. $\times$ V. labrusca $L$. Besides, there were three varieties of complex (European-Amur-American) origin, and five varieties of unknown origin. According to the descriptor [45], the tested set of varieties breaks into 7 ripening groups, that is, ultra-early (up to 105 days from bud break to full ripening of berries) - 13 varieties; very early (106-115 days) - 36; early (116-125 days) - 32; mid-early (126-135 days) — 40; mid-ripening (136-145 days) — 76; mid-late (146-155 days) - 32; and late (156-165 days) -3 varieties.

The varietal dry table wines were produced by micro-winemaking in the laboratory of winemaking technology of the Ya.I. Potapenko All-Russian Research Institute for Viticulture and Winemaking, 
under micro-wine production conditions, according to a unified method in compliance with regulatory documents [46-48].

Scoring of samples of fresh berries and wine was carried out at closed scientific tasting sessions by members of tasting commissions, approved by order of the Director of The Institute from among specialists of the Institute, in accordance with State Standard GOST 32051-2013 [49]. Control samples are always present at tasting sessions of both fresh grapes and wine. The varieties included in the Register of Breeding Achievements Permitted for Use (in the Russian Federation) are taken as control varieties. The name of the variety is disclosed after all members of the tasting committee have given their marks. A score given by an expert represents the sum of points for certain characteristics, the maximum score being 10 points. The score for a variety is obtained by averaging experts' points; the minimum and maximum points are disregarded.

Fresh berries were evaluated by the method of organoleptic analysis accepted for State Variety Testing $[43,50]$. Scoring of fresh grapes is based on the following indicators: cluster appearance (elegance $0.5-1.0$ points, size $0.1-0.5$, density $0.5-1.0$ ); berry appearance (size 0.5-1.0 points, uniformity $0.1-0.5$, transportability $0.5-1.0$ ); and organoleptic assessment (taste 1.0-3.0 points, pulp consistency $0.5-1.0$; skin character $0.1-0.5$; separability, quantity and size of the seed $0.1-0.5$ ).

The wine is evaluated using the following indicators: transparency $0.1-0.5$; color $0.1-0.5$; aroma 1.0-3.0; taste 1.0-5.0; matching the type of wine 0.2-1.0.

In addition to tasting scores, varieties were characterized by a set of 12 agrobiological indicators (Table 2). The study of grape varieties in the collection was carried out using the methods and State Standards generally accepted in viticulture of the Russian Federation [43]; sugar content and acidity were determined according to GOST 27198-87, GOST 32114-2013 [51,52]. The separation force and crushing force were determined according to the method by Prostoserdov N.N. [53].

Table 2. Correlations between taste scores and agrobiological indicators of varieties.

\begin{tabular}{|c|c|c|c|c|c|c|}
\hline \multirow{2}{*}{ Indicator } & \multirow{2}{*}{ Number of Varieties } & \multirow{2}{*}{ Average } & \multirow{2}{*}{ Min } & \multirow{2}{*}{$\operatorname{Max}$} & \multicolumn{2}{|c|}{ Correlation with Taste Scores for } \\
\hline & & & & & Fresh Grapes & Wine \\
\hline Bud break-full ripening of berries (days) & 232 & 130.6 & 99.2 & 157.5 & 0.12 & 0.18 \\
\hline Number of normally developed shoots (pcs.) & 232 & 19.3 & 8.0 & 38.3 & $-0.35 *$ & -0.13 \\
\hline Clusters per shoot & 232 & 0.9 & 0.2 & 2.2 & $-0.30 *$ & $-0.28^{*}$ \\
\hline Clusters per productive shoot & 190 & 1.5 & 1.1 & 2.2 & -0.19 & -0.11 \\
\hline Shoot productivity $(\mathrm{g})$ & 173 & 227.3 & 20.6 & 612.0 & $0.21 *$ & -0.40 * \\
\hline Yield (kg per bush) & 232 & 4.2 & 1.0 & 13.9 & 0.02 & $-0.34 *$ \\
\hline Cluster mass (g) & 232 & 251.0 & 72.4 & 738.7 & 0.54 * & -0.18 \\
\hline Berry mass $(\mathrm{g})$ & 185 & 3.5 & 0.8 & 9.9 & $0.62 *$ & -0.48 * \\
\hline Sugar content $\left(\mathrm{g} 100 \mathrm{~cm}^{-3}\right)$ & 232 & 18.8 & 14.8 & 24.7 & $-0.23 *$ & $0.22 *$ \\
\hline Acidity $\left(\mathrm{g} \mathrm{dm}^{-3}\right)$ & 232 & 7.9 & 4.7 & 12.5 & -0.06 & 0.08 \\
\hline Berry separation force $(\mathrm{g})$ & 41 & 273.1 & 71.0 & 476.6 & $0.48^{*}$ & - \\
\hline Berry crushing force $(\mathrm{g})$ & 41 & 1461.7 & 317.8 & 2671.3 & $0.63 *$ & - \\
\hline
\end{tabular}

There are gaps in the data: clusters per productive shoot was measured for 190 varieties out of a set of 232 varieties, shoot productivity for only 173; berry mass for 185; berry separation force and berry crushing force only for 41 varieties.

\subsection{Data Analysis}

Average perennial values of all characters have been calculated for each variety. The coefficients of the varieties' agrobiological characteristics correlation with taste scores were calculated. The one-way ANOVA using the Tukey HSD test was applied to compare the significance of differences in taste scores between groups of varieties of different origin and with different ripening dates.

The average taste scores for the set of 232 varieties were calculated for each year. When studying the weather dependencies of grapes, the "average variety" data have less random error and a greater dependence on weather conditions $[33,34,43]$. Linear trends of the "average variety" taste scores were determined. Similarly, the "average variety" trends were calculated for each group of interspecies origin. To calculate the trends, the equations of the studied trait regression dependence on the year number 
were built; the significance of the obtained regression coefficient was estimated. For convenience, trend values were multiplied by 10 due to small values of some trends, i.e., they were expressed as the rate of change per decade [54].

Statistical analysis was performed using the Statistica 13.3 package (TIBCO Software, Inc., Palo Alto, CA, USA). The regression agrometeorological models of GS and WS for the "average variety" were constructed by the stepwise regression with forward selection. The monthly mean data and generalized agrometeorological data on heat and moisture availability during the periods with temperatures above $10,15,20,25^{\circ} \mathrm{C}$, that is, the mean temperature, the sum of daily temperatures, degree-days above these thresholds, precipitation and Selyaninov's hydrothermal coefficient (HTC, the ratio of the total precipitation to the sum of temperatures divided by $10[55,56])$, a total of 60 indicators, were used as the possible predictors (Supplement Table S2).

\subsection{Weather Conditions}

This research used the weather data of the meteorological station located in the territory of the Ya.I. Potapenko Don Ampelographic Collection. In 1980-2019, the average sum of temperatures above $10^{\circ} \mathrm{C}$ $\left(\sum \mathrm{T}_{10}\right)$ was $3590^{\circ} \mathrm{C}$ (with minimum $2904^{\circ} \mathrm{C}$, and maximum $4388^{\circ} \mathrm{C}$ ), and the amount of precipitation for the period with temperatures above $10^{\circ} \mathrm{C}$ was $273 \mathrm{~mm}$ (from $134 \mathrm{~mm}$ to $568 \mathrm{~mm}$ ) at collection. A significant increase in $\sum \mathrm{T}_{10}$ for $174.0^{\circ} \mathrm{C}$ per 10 years was observed (the significance level of the trend is $p<0.001)$, while the amount of precipitation did not change significantly, having reduced for $22.3 \mathrm{~mm}$ per 10 years $(p=0.082)$. Since 1990 , warming has been growing intensively; the $\sum \mathrm{T}_{10}$ increase reached $210.0^{\circ} \mathrm{C}$ per 10 years $(p<0.001)$, and precipitation kept decreasing at a rate of $54.4 \mathrm{~mm}$ per 10 years $(p=0.008)$.

\section{Results}

\subsection{Variation of Taste Scores in the Sample}

The long-term average GS varied in the studied varieties from 6.6 to 8.5 points, averaging 7.7 points (Table 1).

The score has no strong correlations, exceeding 0.7 in modulus, with any of the 12 studied agrobiological characteristic (Table 2). Reliable positive correlations of medium strength were found to exist with berry crushing force $(r=0.63)$, berry mass $(r=0.62)$, cluster mass $(r=0.54)$, and the force of berry separation from the pedicel $(r=0.48)$. Negative correlations were found to exist with the number of normally developed shoots $(r=-0.35)$ and the number of clusters per shoot $(r=-0.30)$. Thus, varieties with a large clusters and berries with good transportability have higher GS. The abundance of productive shoots and a large number of clusters per shoot reduce the taste quality.

WS varied little among varieties, from 8.2 to 8.8 points (Table 1), averaging 8.6 points. The small variability in WS is possibly associated with the harvesting of wine varieties when the berries reach certain conditions necessary for processing into a certain type of wine (in this particular case, dry table wine). WS do not have strong correlations with any of the studied indicators, while there exist medium strength negative correlations with berry mass $(\mathrm{r}=-0.48)$, shoot productivity $(\mathrm{r}=-0.40)$, and with yield $(r=-0.34)$. Thus, larger berry mass and shoot productivity reduce wine taste scores of variety.

Groups of varieties of different interspecific origin had different average GS ( $p=0.027$; Figure 2a). The highest average score (7.81) was earned by the varieties represented by complex hybrids with American species. The lowest scores were received by the $V$. vinifera $\times V$. labrusca varieties, the average score being 7.40. The Tukey HSD test confirmed the significance of the difference between these contrasting groups $(p=0.027)$, while no other significant contrasts were found. 


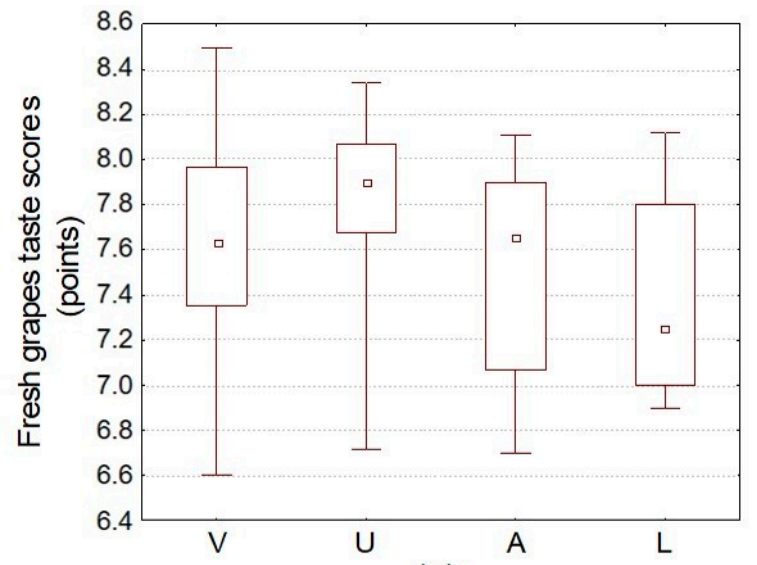

(a)

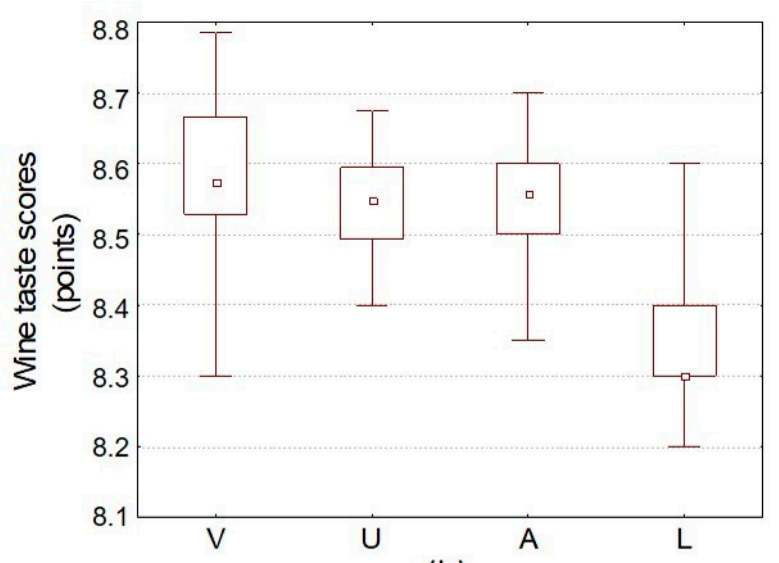

(b)

Figure 2. Taste scores for (a) fresh grapes, (b) wine for the groups of varieties of different interspecies origin. Median, lower, and upper quartiles, min-max are presented. Designations: V-V. vinifera, $\mathrm{U}-$ hybrids with several American species, $\mathrm{A}-\mathrm{V}$. vinifera $\times$ V. amurensis, $\mathrm{L}-V$. vinifera $\times$ V. labrusca.

The "interspecies origin" factor also had a significant impact on WS ( $p<0.001$; Figure 2b). The lowest average WS was 8.36 for the group of $V$. vinifera $\times V$. labrusca varieties, which was significantly lower than those for all other groups ( $p<0.004$ for all groups). The highest WS of 8.60 points was received by $V$. vinifera varieties, and there was no significant difference with the group of $V$. vinifera $\times V$. amurensis varieties with WS of 8.55 points $(p=0.258)$, and the group of complex hybrids with American species with WS of $8.54(p=0.114)$.

The group of ripening did not have a significant effect on GS $(p=0.332)$ or WS $(p=0.784)$.

\subsection{Correlation Analysis of Taste Scores of "Average Variety"}

The year-to-year GS variability had a significantly positive correlation with cluster weight $(\mathrm{r}=0.53$, $p<0.001)$, yield per bush $(\mathrm{r}=0.45, p=0.004)$, shoot productivity $(\mathrm{r}=0.39 p=0.014)$, and a negative correlation with acidity $(\mathrm{r}=-0.45, p=0.004)$.

The year-to-year WS variability was not significantly associated with any other indicator. The highest relation was with sugar content $(\mathrm{r}=0.36)$, but it was not significant $(p=0.118)$. Other relations were weak and insignificant, in particular, there was no relation with the ripening period duration $(\mathrm{r}=0.03, p=0.902)$.

The strongest positive correlation between the "average variety" GS was observed (Supplement Table S2) with the average temperature during the period of steady transition to temperatures above $15^{\circ} \mathrm{C}(\mathrm{r}=0.71$, $p<0.001)$, the sum of degree-days above $20^{\circ} \mathrm{C}(\mathrm{r}=0.68, p<0.001)$, and the temperature in August $(\mathrm{r}=0.66$, $p<0.001$ ), while the strongest negative correlation exists with HTC for the period with temperatures above $20{ }^{\circ} \mathrm{C}(\mathrm{r}=-0.63, p<0.001)$, above $25^{\circ} \mathrm{C}(\mathrm{r}=-0.60, p=0.012)$, and with precipitation in August $(\mathrm{r}=-0.53$, $p=0.001)$.

The "average variety" WS has only negative reliable correlations with agroclimatic indicators, namely with precipitation for the period with temperatures above $20^{\circ} \mathrm{C}\left(P_{20}, \mathrm{r}=-0.73\right)$, precipitation in August $(\mathrm{r}=-0.61, p=0.004)$ and June $(\mathrm{r}=-0.53, p=0.017)$, for the period with temperatures above $10{ }^{\circ} \mathrm{C}(\mathrm{r}=-0.46, p=0.042), \mathrm{HTC}_{20}(\mathrm{r}=-0.66, p=0.001)$.

\subsection{Regression Analysis of Taste Scores Year-to-Year Variation}

For 1981-2019, the average GS for the sample showed a tendency to increase (Figure 3) for 0.15 points per 10 years $(p<0.001$ ), while WS did not change significantly in 2000-2019, and the rate of change was 0.02 points per 10 years $(p=0.444)$. All groups of different origin had significant $(p<0.050)$ trends to increase of GS (from 0.09 to 0.53 points per 10 years) and had no significant trends of WS. To check the trend of the "average variety" the taste score trends for the varieties with the 
longest observation period were calculated. The trend of GS for Moldova variety was 0.20 points per 10 years within 28 years of observations $(p=0.001)$, and the trend of WS for Krasnostop Zolotovsky variety was insignificant ( 0.01 points per 10 years) within 16 years $(p=0.282)$. Trends in these varieties are comparable with that for the "average variety".

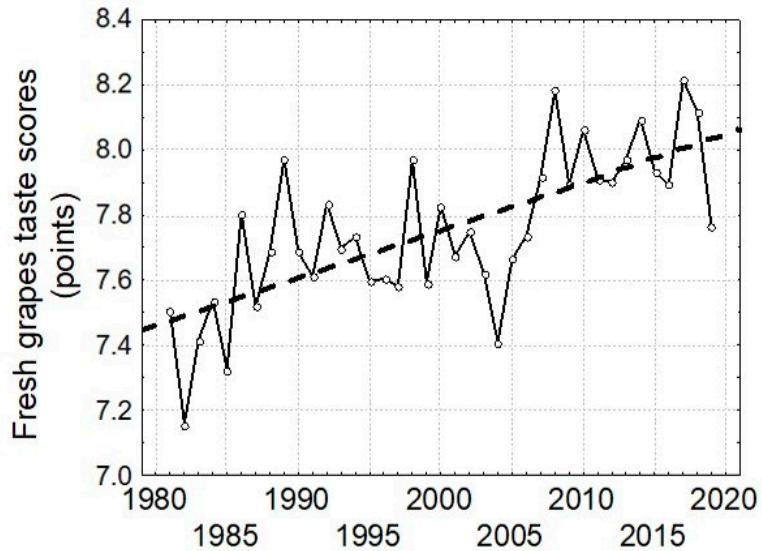

(a)

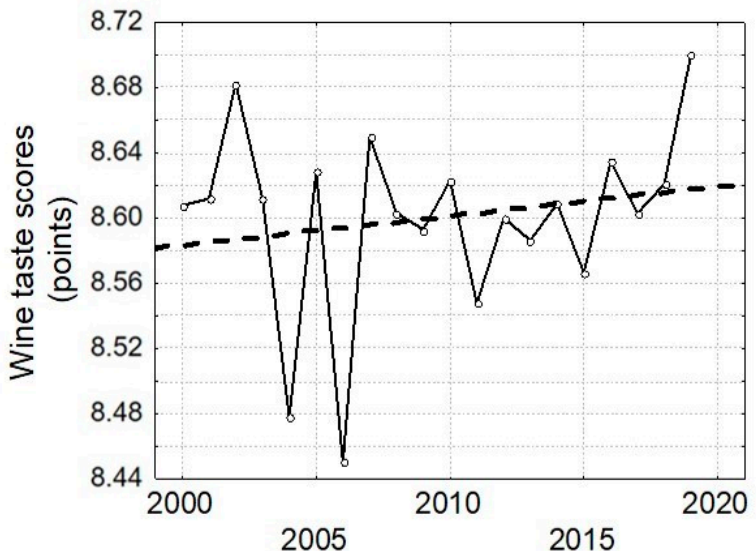

(b)

Figure 3. Dynamics of the average taste scores of (a) fresh grapes, (b) wine. Designations: solid line actual data; dotted line-calculated linear trend.

The regression with forward selection of variables revealed only one significant predictor for every model. GS increased by an average of 0.139 points with an increase in temperatures above $15^{\circ} \mathrm{C}$ $\left(T_{15}\right)$ by $1{ }^{\circ} \mathrm{C}$ :

$$
\text { GS }=4.773+0.139 T_{15} \quad R^{2}=0.50 \quad(0.000 ; 0.000)
$$

Here, $R^{2}$ is the equation determination coefficient; significance level for regression coefficients is given in parentheses. The root mean square error (RMSE) of the model is 0.17 points; the actual and calculated values correlation coefficient is 0.71 (Figure $4 \mathrm{a}$ ).

An increase by $1 \mathrm{~mm}$ in precipitation for the period with temperatures above $20^{\circ} \mathrm{C}\left(P_{20}\right)$ :

$$
W S=8.712-0.001 P_{20} \quad R^{2}=0.53 \quad(0.000 ; 0.007)
$$

The RMSE of the model is 0.04 points, the coefficient of the actual and calculated values correlation is 0.73 (Figure $4 b$ ).

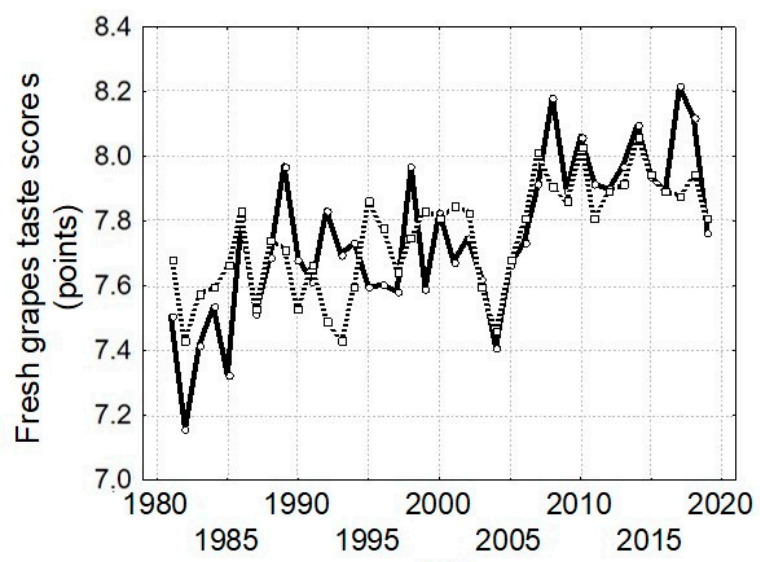

(a)

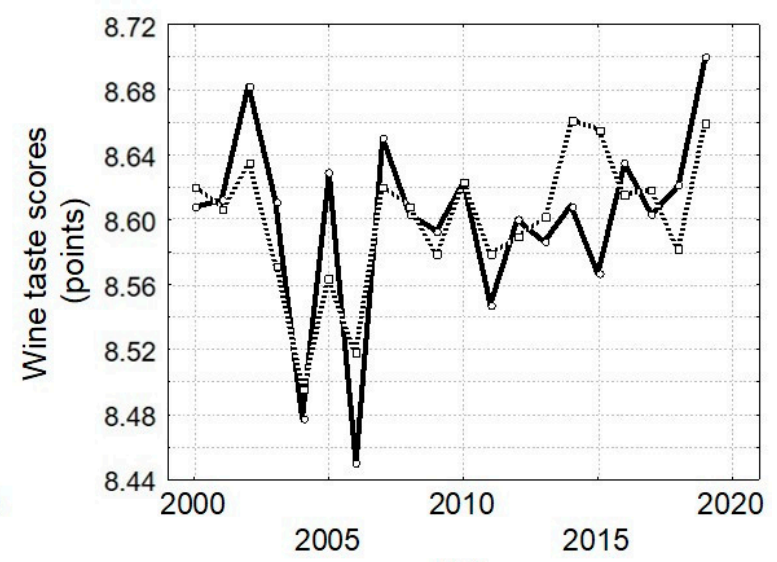

(b)

Figure 4. Verification of taste scoring models for: (a) fresh grapes; (b) wine. Designations: solid line—actual values, dotted line-calculated values. 
The models explain 50 and $53 \%$ of the variability, i.e., half or more of it, which makes it possible to forecast the climate-related trend of tasting scores. However, the remaining $50 \%$ and $47 \%$, respectively, are caused by other random factors, such as extreme weather events, atypical seasonal course of temperature and precipitation, diseases, and conditions of the previous growing season.

The largest errors in GS model were in 1992, 1993, and 2017, when actual values were $0.27-0.34$ points higher than the model. These years were characterized by a long period with temperatures favorable for vegetative growth of $15-20{ }^{\circ} \mathrm{C}$ up to $36-40$ days vs. the average perennial 18 days, which, under favorable conditions for further vegetation, created the basis for high quality of berries of table varieties, despite the fact that the average summer temperature was not very high.

In 1982, 1985, and 1995, the actual GS values turned out to be $0.27-0.34$ points lower than the forecasted ones. Unfavorable winter conditions were observed in 1982 and 1985, when the temperature in February was $-8.8^{\circ} \mathrm{C}$ and $9.7^{\circ} \mathrm{C}$ vs. the long-term average of $-3^{\circ} \mathrm{C}$, and a significant number of days had temperatures below $-15{ }^{\circ} \mathrm{C}$ ( 14 and 31 days vs. the long-term average of 9 days). These circumstances led to a reduced quality of berries in the summer with a heat availability below average (the average temperature above $15^{\circ} \mathrm{C}$ was $19.2^{\circ} \mathrm{C}$ and $20.9^{\circ} \mathrm{C}$ vs. the norm of $21.5^{\circ} \mathrm{C}$ ).

The calculated scores of wine quality reflected the extremely low WS values in the humid 2004 and 2006. The largest errors of the wine quality model were observed in 2015 and 2014, when the calculated values exceeded the actual ones by 0.09 and 0.05 points, respectively. This is associated with extremely low precipitation during the period of berry formation: the total of 12 and $15 \mathrm{~mm}$ of precipitation, respectively, fell in July-August. In 2002 and 2005, on the contrary, the actual values were higher than the calculated ones by $0.05-0.06$ points, which is associated with the low value of the average number of clusters per productive shoot (1.37 and $1.42 \mathrm{vs}$. the long-term average of 1.54 ) in these years.

The factors identified by the regression analysis had the following trends 1981-2019: $v_{T_{15}}=0.73^{\circ} \mathrm{C}$; per 10 years $(\mathrm{p}=0.000)$, and $v_{P_{20}}=-15.43 \mathrm{~mm}$ per 10 years $(p=0.059)$. The rates of changes in taste scores calculated by the models were as follows: $v_{G S}=0.10$ points per 10 years, and $v_{W S}=0.01$ points per 10 years. Since 1990, the changes have become more intense and have reached $v_{T_{15}}=0.94{ }^{\circ} \mathrm{C}$ per 10 years $(p=0.000), v_{P_{20}}=-18.85 \mathrm{~mm}$ per 10 years $(p=0.121)$, and the estimated rates of changes in taste scores became $v_{G S}=0.13$ points per 10 years, and $v_{W S}=0.02$ points per 10 years.

\section{Discussion}

Expert tasting is the main tool for evaluating the taste qualities of test samples by analyzing their organoleptic properties. An expert judgment contains a significant subjective component; for example, the results of tasting are influenced by the composition of experts, their number, the physiological characteristics of each expert at the time of tasting, subjectivity in the perception of organoleptic properties, unbalanced wines, etc. [2]. Despite its subjectivity, expert tasting assessment remains the main method for determining consumer preferences [3-5]. At the same time, as our experience shows, even subjective qualities determined by expert methods show dependence on the meteorological conditions of the year. For example, elegance (nice and attractive appearance) depends on the weather conditions of a particular year; the drier the year, the more beautiful the berries are in pink or white varieties, as they turn amber color. With a large amount of precipitation, the pulp of some table varieties becomes more liquid, and the variety will be less transportable. The tastes could change from year to year, additionally building up the error of estimates. However, there is no reason to suspect that the changes in taste over 39 years have had any definite trend that would go beyond an accidental error.

A search for the factors affecting the taste scores of viticulture products from the varieties of the Ya.I. Potapenko Don Ampelographic Collection revealed that GS were negatively correlated with the number of elements of bush productivity, and WS was also negatively associated with the berry mass and yield, i.e., a high yield under conditions of limited resources may be accompanied by a reduced quality of the crop $[34,38,42]$. The literature notes the need to adapt summer pruning operations to climate change [7]. 
In addition, taste scores depended on the origin of the variety: the lowest scores for both fresh grapes and wine were earned by the group of $V$. vinifera $\times V$. labrusca varieties due to the persistent "foxy" aroma inherent to V. labrusca, which is often rated negatively by the consumers $[57,58]$. The highest average GS were earned by the varieties representing complex hybrids with American species. This group is characterized by the largest berries among the varieties in the studied set. These are varieties mainly bred in Europe with the use of Seyve Villard and the Central Asian variety Katta Kurgan as a parent.

The regression analysis showed that the limiting factors of taste scores of viticulture products near the northern border of the zone of industrial viticulture in the European Russia are heat deficiency and excess rainfall. Fifty percent of the year-to-year variation of GS is determined by the variation of the average temperature above $15{ }^{\circ} \mathrm{C}$. Table grape varieties require a hot and dry climate for the formation of a sufficient amount of carbohydrates that determine the degree of maturity, color saturation, and sweetness of berries [59]. The observed increase of the precipitation to temperatures ratio during the period with temperatures above $15^{\circ} \mathrm{C}$ has a positive effect on the sugar content and negatively on the titratable acidity of grape berries at the Ya.I. Potapenko Don Ampelographic Collection $[16,17]$.

Fifty-three percent of wine taste scores variation is determined by the sum of precipitation within the period with temperatures above $20^{\circ} \mathrm{C}$. A transition to temperatures above $20^{\circ} \mathrm{C}$ correlates with the onset of flowering in grapes [34]. For the formation of an ovary of grapes, light short-term rains after flowering are favorable, while heavy rainfall is harmful, as it washes pollen off, worsens pollination conditions, contributes to the spread of mildew, and subsequent cracking of berries [60]. Dry weather during ripening generally favors the production of high-quality wines [10,38].

In agroclimatology of grapes, the ripening time is associated with a sum of temperature above $10^{\circ} \mathrm{C}[10,22,33,37,61]$; however, in some studies, it is shown that the phenological events of the grapes are related to the temperature limits of 15 and $20^{\circ} \mathrm{C}$ [62-64]: in the North Caucasus and Transcaucasia, the date of flowering onset is $30-32$ days past the date of steady transition through $15^{\circ} \mathrm{C}$. Maturation in Azerbaijan begins 87 days after the date of temperature transition through $20^{\circ} \mathrm{C}$, and grape harvesting takes place in 98-125 days, depending on the place of growth. Our study confirmed the importance of the characteristics of the periods with temperature above these limits. Such generalized agroclimatic indices are convenient for creating regression models under climate change conditions, because dependencies remain true when phenological events are shifted to other months.

Despite the fact that wine tasting ratings did not have a reliable trend, there was a slight increase in it over the years. The model's climate-related forecast is also positive. All this suggests that the observed weak trend in wine scores is related to decreasing precipitation; however, it is too small against the background of year-to-year fluctuations and will become reliable over a longer observation period.

In recent decades, the average GS have increased in groups of varieties of various interspecies origin for 0.15 points per 10 years, and the WS have not changed. The previously performed analysis of trends in groups of varieties of various interspecific origin and type of use at the Don Ampelographic Collection showed [16] that varieties do not differ in trends of the long-term dynamics of most indicators. All groups demonstrated a decrease in the ripening time for 2 days per 10 years, an increase in yield for $1 \mathrm{~kg}$ per bush per 10 years and sugar content for $2 \mathrm{~g} 100 \mathrm{~cm}^{-3}$ per 10 years, a decrease in acidity of $1 \mathrm{~g} \mathrm{dm}^{-3}$, which corresponds to the trends observed in other countries [65].

Thus, the observed climate warming is favorable for viticulture in the northern zone of industrial viticulture in Russia. In more southern regions of traditional viticulture, a temperature increase above the temperature optimum and a reduction in precipitation may have a negative effect on the quality of berries $[14,18,25,34]$. The obtained results suggest that grape cultivation can be promoted northward under conditions of increasing heat and decreasing moisture availability [19,66-68]. 


\section{Conclusions}

The analysis of grape varieties of the Ya.I. Potapenko Don Ampelographic Collection showed that taste scores of viticulture products depended on the interspecies origin of the variety; the lowest scores were of the group of $V$. vinifera $\times V$. labrusca hybrids.

In recent decades, the average taste scores of fresh grapes have increased in groups of varieties of various interspecies origin, and wine scores have not changed.

An analysis of the relationship between taste scores of fresh berries and wines with agrometeorological conditions showed that the year-to-year variability of the former is determined by 50 or more percent by the weather conditions of the harvest year. In the conditions of the northern zone of industrial viticulture in Russia, the weather factor limiting the quality of table grapes is the lack of heat, namely, of temperatures above $15^{\circ} \mathrm{C}$. The quality of the wine decreases in years with excessive midsummer rainfall, namely in the period with temperatures above $20^{\circ} \mathrm{C}$.

The observed climate warming leads to an increase in the sugar content, increase in grape yield, and in taste scores for the quality of fresh berries, i.e., is favorable for grapevine cultivation in the northern zone of industrial viticulture in Russia.

Supplementary Materials: The following are available online at http://www.mdpi.com/2073-4395/10/10/1613/s1, Table S1. Characteristics of 232 grape varieties in conditions of the Don Ampelographic Collection, 1981-2019, Table S2. The correlation coefficients between the tasting scores of fresh berries and wine of the "average variety" with agrometeorological indicators.

Author Contributions: Conceptualization, data analysis, visualization, writing, L.Y.N.; preparing data, writing L.G.N. All authors have read and agreed to the published version of the manuscript.

Funding: The work was supported by Grant No. 18-016-00213 of the Russian Foundation for Basic Research in part of database creation, regression analysis, and influence of climate changes.

Acknowledgments: The polymorphism of ampelographic collection was performed within the framework of the State Assignment No. 0662-2019-0004.

Conflicts of Interest: The authors declare no conflict of interest.

\section{References}

1. Amerine, M.A.; Pangborn, R.M.; Roessler, E.B. Principles of sensory evaluation of food. In Food Science and Technology Monographs; Academic Press: New York, NY, USA, 1965; pp. 399-431.

2. Khalaphyan, A.A.; Temerdashev, Z.A.; Guguchkina, T.I.; Yakuba, Y.T. Computer analysis of expert evaluation of the organoleptic quality indexes of wines. Anal. Control 2017, 21, 161-172. [CrossRef]

3. Sonego, L.; Lurie, S.; Zuthi, Y.; Kaplonov, T.; Ben-Arie, R.; Kosto, I. Factors affecting taste scores of early season seedless table grape cv. Mystery and Prime. J. Agric. Food Chem. 2002, 50, 544-548. [CrossRef]

4. Muñoz-Robredo, P.; Robledo, P.; Manríquez, D.; Molina, R.; Defilippi, B.G. Characterization of sugars and organic acids in commercial varieties of table grapes. Chil. J. Agric. Res. 2011, 71, 452-458. [CrossRef]

5. Francis, I.L.; Williamson, P.O. Application of consumer sensory science in wine research. Aust. J. Grape Wine Res. 2015, 21, 554-567. [CrossRef]

6. Cortez, P.; Cerdeira, A.; Almeida, F.; Matos, T.; Reis, J. Modeling wine preferences by data mining from physicochemical properties. Decis. Support Syst. 2009, 47, 547-553. [CrossRef]

7. Poni, S.; Gatti, M.; Palliotti, A.; Dai, Z.; Duchêne, E.; Truong, T.-T.; Ferrara, G.; Matarrese, A.M.S.; Gallotta, A.; Bellincontro, A.; et al. Grapevine quality: A multiple choice issue. Sci. Hortic. 2018, 234, 445-462. [CrossRef]

8. Champa, W.A.H.; Gill, M.I.S.; Mahajan, B.V.C.; Aror, N.K.; Bedi, S. Brassinosteroids Improve Quality of Table Grapes (Vitis vinifera L.) cv. Flame Seedless. Trop. Agric. Res. 2015, 26, 368-379. [CrossRef]

9. Jones, G. Climate, Grapes, and Wine: Structure and Suitability in a Changing Climate. Acta Hort. 2012, 931, 19-28. [CrossRef]

10. Santos, J.A.; Fraga, H.; Malheiro, A.C.; Moutinho-Pereira, J.; Dinis, L.-T.; Correia, C.; Moriondo, M.; Leolini, L.; Dibari, C.; Costafreda-Aumedes, S.; et al. A Review of the Potential Climate Change Impacts and Adaptation Options for European Viticulture. Appl. Sci. 2020, 10, 3092. [CrossRef] 
11. De Orduña, M.R. Climate change associated effects on grape and wine quality and production. Food Res. Int. 2010, 43, 1844-1855. [CrossRef]

12. Leeuwen, C.; Darriet, P. The impact of climate change on viticulture and wine quality. J. Wine Econ. 2016, 11, 150-167. [CrossRef]

13. Bardaji, I.; Iraizoz, B. Uneven responses to climate and market influencing the geography of high-quality wine production in Europe. Reg. Env. Chang. 2015, 15, 79-92. [CrossRef]

14. Biasi, R.; Brunori, E.; Ferrara, C.; Salvati, L. Assessing impacts of climate change on phenology and quality traits of Vitis vinifera L.: The contribution of local knowledge. Plants 2019, 8, 121. [CrossRef] [PubMed]

15. Hewer, M.; Brunette, M. Climate Change Impact Assessment on Grape and Wine for Ontario, Canada's Appellations of Origin. Reg. Environ. Chang. 2020, 20, 1-15. [CrossRef]

16. Novikova, L.Y.; Naumova, L.G. Structuring ampelographic collections by phenotypic characteristics and comparing the reaction of grape varieties to climate chane. Vavilov J. Genet. Breed. 2019,23,772-779. [CrossRef]

17. Novikova, L.Y.; Naumova, L.G. Trends of changes in sugar content and acidity of grape varieties from the collection of All-Russian Scientific Research Institute of Viticulture and Winemaking named after Y.I. Potapenko. Winemak. Vitic. 2013, 6, 54-57.

18. Petrov, V.S.; Aleynikova, G.Y.; Novikova, L.Y.; Naumova, L.G.; Lukyanova, A.A. The influence of climate changes on the grape phenology. Fruit Grow. Vitic. South Russ. 2019, 57, 29-50. [CrossRef]

19. Safonov, G.; Safonova, Y. Economic analysis of the impact of climate change on agriculture in Russia national and regional aspects. Oxfam Res. Rep. 2013, 1-48. Available online: www.oxfam.org (accessed on 5 August 2020).

20. Choudhury, A.; Jones, J. Crop yield prediction using time series models. J. Econ. Econ. Educ. Res. 2014, $15,53-67$.

21. Molitor, D.; Junl, J.; Evers, D.; Hoffmann, L.; Beyer, M. A high-resolution cumulative degree day-based to simulate phonological development of grapevine. Am. J. Enol. Vitic. 2014, 65, 72-80. [CrossRef]

22. Quenol, H.; Grosset, M.; Barbeau, G.; van Leeuwen, K.; Hofmann, M.; Foss, C.; Irimia, L.; Rochard, J.; Boulanger, J.-P.; Tissot, C.; et al. Adaptation of viticulture to climate change: High resolution observation of adaptation scenario for viticulture. Bull. de l'OIV. 2014, 87, 385-406.

23. Fraga, H.; Pinto, J.G.; Santos, J.A. Climate change projections for chilling and heat forcing conditions in European vineyards and olive orchards: A multi-model assessment. Clim. Chang. 2019, 152, 179-193. [CrossRef]

24. Costa, R.; Fraga, H.; Fonseca, A.; de Cortazar-Atauri, I.G.; Val, M.C.; Carlos, C.; Reis, S.; Santos, J.A. Grapevine phenology of cv. Touriga Franca and Touriga Nacional in the Douro Wine Region: Modelling and climate change projections. Agronomy 2019, 9, 210. [CrossRef]

25. Romero, P.; Gil-Muñoz, R.; del Amorc, F.M.; Valdés, E.; Fernández, J.I.; Martinez-Cutillasa, A. Regulated deficit irrigation based upon optimum water status improves phenolic composition in Monastrell grapes and wines. Agric. Water Manag. 2013, 121, 85-101. [CrossRef]

26. Chrysargyris, A.; Xylia, P.; Litskas, V.; Stavrinides, M.; Heyman, L.; Demeestere, K.; Höfte, M.; Tzortzakis, N. Assessing the Impact of Drought Stress and Soil Cultivation in Chardonnay and Xynisteri Grape Cultivars. Agronomy 2020, 10, 670. [CrossRef]

27. Richardson, A.D.; Anderson, R.S.; Arain, M.A.; Barr, A.G.; Bohrer, G.; Chen, G.; Chen, J.M.; Ciais, P.; David, K.J.; Desai, A.R.; et al. Terrestrial biosphere models need better representation of vegetation phenology: Results from the North American Carbon Program Site Synthesis. Glob. Chang. Biol. 2012, 18, 566-584. [CrossRef]

28. Jones, G.V.; White, M.A.; Cooper, O.R.; Storchmann, K. Climate change and global wine quality. Clim. Chang. 2005, 73, 319-343. [CrossRef]

29. Macqueen, R.W.; Meinert, L.D. (Eds.) Fine Wine and Terroir-The Geoscience Perspective; Geological Association of Canada Geoscience, Canada Reprint Series: St. John's, NL, Canada, 2006; ISBN 978-1-897095-21-8.

30. Gladstones, J. Wine, Terroir and Climate Change; Wakefield Press: Kent Town, South Australia, 2011; 280p.

31. Foroni, F.; Vignando, M.; Aiello, M.; Parma, V.; Paoletti, M.G.; Squartini, A.; Rumiati, R. The smell of terroir! Olfactory discrimination between wines of different grape variety and different terroir. Food Qual. Prefer. 2017, 58, 18-23. [CrossRef]

32. Zombardo, A.; Mica, E.; Puccioni, S.; Perria, R.; Valentini, P.; Mattii, G.B.; Cattivelli, L.; Storchi, P. Berry quality of grapevine under water stress as affected by rootstock-scion interactions through gene expression regulation. Agronomy 2020, 10, 680. [CrossRef] 
33. Leeuwen, C.; Friant, P.; Chone, X.; Tregoat, O.; Koundouras, S.; Dubourdieu, D. Influence of climate, soil and cultivar on terroir. Am. J. Enol. Vitic. 2004, 55, 207-217.

34. Davitaia, F.F. Climatic Zones of Grapes in the USSR; Pishchepromizdat: Moscow, Russia, 1948; 192p. (In Russian)

35. Failla, O.; Mariani, L.; Brancadoro, L.; Minelli, R.; Scenza, A.; Murada, G.; Mancini, S. Spatial distribution of solar radiation and its effect on vine phenology and grape ripening in an Alpine environment. Am. J. Enol. Vitic. 2004, 55, 128-138.

36. Lima, M.S.; Dutra, M.C.P.; Toaldo, I.A.; Corrêa, L.C.; Pereira, G.E.; Oliveira, D.; Bordignon-Luiz, M.T.; Ninow, J.L. Phenolic compounds, organic acids and antioxidant activity of grape juices produced in industrial scale by different processes of maceration. Food Chem. 2015, 188, 384-392. [CrossRef] [PubMed]

37. Silva, L.R.; Queiroz, M. Bioactive compounds of red grapes from Dão region (Portugal): Evaluation of phenolic and organic profile. Asian Pac. J. Trop. Biomed. 2016, 6, 315-321. [CrossRef]

38. Ramos, M.C.; Jones, G.V.; Martinez-Casasnovas, J.A. Structure and trends in climate parameters affecting winegrape production in northeast Spain. Clim. Res. 2008, 38, 1-15. [CrossRef]

39. Davenport, J.R.; Keller, M.; Mills, L.J. How cold can you go? Frost and winter protection for grape. HortScience 2008, 43, 1966-1969. [CrossRef]

40. Ferguson, J.C.; Tarara, L.J.; Mills, L.J.; Groeve, G.G.; Keller, M. Dynamic thermal time model of codhardiness for dormant grapevine buds. Ann. Bot. 2011, 107, 389-396. [CrossRef] [PubMed]

41. Lorenzo, M.N.; Taboada, J.J.; Lorenzo, J.F.; Ramos, A.M. Influence of climate on grape production and wine quality in the Rías Baixas, north-western Spain. Reg. Environ. Chang. 2013, 13, 887-896. [CrossRef]

42. Baeza, P.; Junquera, P.; Peiro, E.; Lissarrague, R.J.; Uriarte, D.; Vilanova, M. Effects of vine water status on yield components, vegetative response and must and wine composition. Adv. Grape Wine Biotechnol. IntechOpen 2019. [CrossRef]

43. Lazarevsky, M.A. The Study of Grape Varieties; Publishing House of the Rostov University: Rostov-on-Don, Russia, 1963; 151p. (In Russian)

44. Afonin, A.N.; Greene, S.L.; Dzyubenko, N.I.; Frolov, A.N. Interactive Agricultural Ecological Atlas of Russia and Neighboring Countries. Economic Plants and their Diseases, Pests and Weeds. 2008. Available online: http://www.agroatlas.ru/en (accessed on 5 October 2020).

45. Office International de la Vigneet du Vin. O.I.V. Code des Caractères Descriptifs des Variétés et Espèces de Vitis-Descriptor List for Grape Vine Varieties and Vitis Species; Office International de la Vigneet du Vin. O.I.V: Paris, France, 1983; 553p.

46. All-Union Scientific Research Institute of Winemaking and Viticulture "Magarach". Collection of Technological Instructions, Rules and Regulatory Materials for the Wine Industry; Valuiko, G.G., Ed.; Agropromizdat: Moscow, Russia, 1985; 51p. (In Russian)

47. GOST 32030-2013. Table Wines and Table Winestocks. General Specifications; Standartinform: Moscow, Russia, 2014; 12p. (In Russian)

48. GOST 31782-2012. Fresh Grape of Combine and Hand Harvesting for Industrial Processing. Specifications; Standartinform: Moscow, Russia, 2014; 8p. (In Russian)

49. GOST 32051-2013. Wine Products. Methods of Organoleptic Analysis; Standartinform: Moscow, Russia, 2013; 16p. (In Russian)

50. State Commission for the Testing of Agricultural Crop Varieties, under the USSR Ministry of Agriculture. Methodology for State Variety Testing of Agricultural Crops. Issue V, Fruit, Berry, Subtropical, Citrus, Nut Crops, Grapes and Tea; Kolos Publishers: Moscow, Russia, 1970; 158p. (In Russian)

51. GOST 27198-87. Fresh Grapes. Methods for Determination of Mass Concentration of Sugars; IPK Standards Publishing House: Moscow, Russia, 2000; 8p. (In Russian)

52. GOST 32114-2013. The Alcohol Production and Raw Material for it Producing. Methods for Determination of Titrating Acids; Standartinform: Moscow, Russia, 2013; 8p. (In Russian)

53. Prostoserdov, N.N. Study of Grapes for Determining Their Use (Uvology); Pishchepromizdat: Moscow, Russia, 1963; 79p. (In Russian)

54. Lindsey, R.; Dahlman, L. Climate Change: Global Temperature Science \& Information for a Climate-Smart Nation. 2020. Available online: https://www.climate.gov/news-features/understanding-climate/climatechange-global-temperature (accessed on 5 October 2020).

55. Selyaninov, G.T. About climate agricultural estimation. Proc. Agric. Meteorol. 1928, 20, 165-177. (In Russian) 
56. Integrated Drought Management Program. 2018. Available online: https://www.droughtmanagement.info/ hydro-thermal-coefficient-of-selyaninov-htc (accessed on 6 October 2020).

57. Biasoto, A.C.T.; Netto, F.M.; Marques, E.J.N.; da Silva, M.A.A.P. Acceptability and preference drivers of red wines produced from Vitis labrusca and hybrid grapes. Food Res. Int. 2014, 62, 456-466. [CrossRef]

58. Teissedre, P.-L. Composition of grape and wine from resistant vine varieties. OENO One 2018, 52, 189-195. [CrossRef]

59. FAO. FAO-OIV Focus-Table and Dried Grapes; FAO: Rome, Italy, 2016; 64p, Available online: http://www.fao. org/3/a-i7042e.pdf (accessed on 24 June 2020).

60. González-Fernández, E.; Piña-Rey, A.; Fernández-González, M.; Aira, M.J.; Rodríguez-Rajo, F.J. Prediction of Grapevine Yield Based on Reproductive Variables and the Influence of Meteorological Conditions. Agronomy 2020, 10, 714. [CrossRef]

61. Parker, A.; de Cortazar-Atauri, I.; van Leeuwen, C.; Chuine, I. General phenological model to characterise the timing of flowering and veraison of Vitis vinifera L. Aust. J. Grape Wine Res. 2011, 17, 206-216. [CrossRef]

62. Lazarevsky, M.A. The Role of Heat in the Life of the European Vine; Publishing House of the Rostov University: Rostov-on-Don, Russia, 1961; 100p. (In Russian)

63. Melnik, Y.S.; Gulinova, N.V.; Bedarev, S.A. Guide to Agrometeorological Forecasts. V.2. Commercial, Vegetable, Fruit, Subtropical Crops, Herbs, Pasturable Vegetation, Distant-Pasture Livestock Production; Gidrometeoizdat: Leningrad, Russia, 1984; 264p. (In Russian)

64. Naumova, L.G.; Novikova, L.Y. Temperature analysis of interphase periods of grape varieties in the collection of All-Russian Scientific Research Institute of Viticulture and Winemaking named after Y. I. Potapenko. Winemak. Vitic. 2015, 5, 46-50.

65. Vršič, S.; Vodovnik, T. Reactions of grape varieties to climate changes in North East Slovenia. Plant Soil Environ. 2012, 58, 34-41. [CrossRef]

66. White, M.A.; Diffenbaugh, N.S.; Jones, G.V.; Pal, J.S.; Giorgi, F. Extreme heat reduces and shifts United States premium wine production in the 21st century. Proc. Natl. Acad. Sci. USA 2006, 103, 11217-11222. [CrossRef]

67. Schultz, H.R.; Jones, G.V. Climate induced historic and future changes in viticulture. J. Wine Res. 2010, 21, 137-145. [CrossRef]

68. Roy, P.; Grenier, P.; Barriault, E.; Logan, T.; Blondlot, A.; Bourgeois, G.; Chaumont, D. Probabilistic climate change scenarios for viticultural potential in Québec. Clim. Chang. 2017, 143, 43-58. [CrossRef]

Publisher's Note: MDPI stays neutral with regard to jurisdictional claims in published maps and institutional affiliations.

(C) 2020 by the authors. Licensee MDPI, Basel, Switzerland. This article is an open access article distributed under the terms and conditions of the Creative Commons Attribution (CC BY) license (http://creativecommons.org/licenses/by/4.0/). 